\title{
Rancang Bangun Aplikasi Al Wirdul Jalil Berbasis Mobile
}

\author{
Hariman Bahtiar ${ }^{1}$, Baiq Andriska Candra Permana ${ }^{2}$, Maspuk Al Hamdani ${ }^{3}$ \\ 1,3Program Studi Sistem Informasi, Universitas Hamzanwadi \\ 2Program Studi Teknik Informatika, Universitas Hamzanwadi \\ *harimaob@gmail.com
}

\begin{abstract}
Abstrak
Wirdul jalil merupakan kumpulan doa dan zikir yang disusun oleh TGH. Afifudin Adnan salah satu murid dari Mawlanasysyaikh Tuan Guru Kyai Hajji Muhammad Zainuddin Abdul Madjid dan sekaligus pendiri Yayasan Al Mukhtariyah Al Islamiyah. Wirdul jalil sudah menjadi bacaan wajib untuk jam'ah dan murid Yayasan Al Mukhtariah Al Islamiyah dan hampir setiap tahunnya, pondok pesantren Al Mukhtariyah Al Islamiyah mencetak wirdul jalii. Kemudian di bagikan untuk murid dan jama'ah Al Mukhtariyah AI IsImiyah untuk mengganti wirdul yang telah rusak dimakan usia atau hilang. Dengan adanya permasalahan di atas, penulis bermaksud merancang dan membangun sebuah aplikasi mobile yang dapat memduahkan jam'ah dan murid Yayasan $\mathrm{Al}$ Mukhtariah Al Islamiyah dalam mendaptakan wirdul jalil tampa harus mencetaknya terlebih dahulu, dengan adanya aplikasi tersebut jama'ah dan murid Yayasan Al Mukhtariah Al Islamiyah dapat memasangnya di perangkat mobile. dengan begitu, jama'ah dan murid dapat membaca wirdul jalil secara peraktis di perangkat mobile mereka, dan pada akhirnya aplikasi bisa di manfaatkan lebih lanjut.
\end{abstract}

\section{Kata Kunci :}

\begin{abstract}
Wirdul jalil is a collection of prayers and dhikr compiled by TGH. Afifudin Adnan is a student of Mawlanasysyaikh Tuan Guru Kyai Hajji Muhammad Zainuddin Abdul Madjid and also the founder of the Al Mukhtariyah Al Islamiyah Foundation. Wirdul jalil has become compulsory reading for congregations and students of the Al Mukhtariah Al Islamiyah Foundation and almost every year, the Al Mukhtariyah Al Islamiyah Islamic boarding school prints wirdul jalil. Then it was distributed to students and the congregation of Al Mukhtariyah Al Islmiyah to replace wirdul that had been damaged by age or lost. With the above problems, the author intends to design and build a mobile application that can produce jam'ah and students of the Al Mukhtariah Al Islamiyah Foundation in getting wirdul jalil without having to print it first, with this application congregations and students of the Al Mukhtariah Al Foundation Islamiyah can install it on a mobile device. That way, the congregation and students can read Wirdul Jalil practically on their mobile devices, and in the end the application can be used further.
\end{abstract}

Keywords: Wirdul Jalil, Mobile Applications, Prayer and Recitation

\section{Pendahuluan}

Dengan perkembangan teknologi yang semakin canggih, pemanfaatan perangkat Mobile sebagai pendamping dalam kehidupan sehari-hari sudah sangat lumrah bagi ummat manusia. Hal ini dikarenakan beberapa perangkat Mobile sudah memiliki fitur dan kemampuan lebih dari sekedar fungsi dasarnya yaitu untuk menelpon dan SMS. Saat ini pengguna perangkat Mobile semakin banyak serta jenis yang beragam serta sistem operasi yang selalu terupdate dan perangkat Mobile yang munggunakan sistem operasi android paling banyak di gunakan dengan 
mobilitas tinggi mengakibatkan masyarakat kaum muslim anak-anak sampai dewasa umumnya tidak sempat membaca buku kumpulan doa-doa. Hal tersebut menjadi gagasan bagi penulis untuk membuat sebuah aplikasi yang berisi doa dan zikir khususnya untuk para santri dan santriwati yayasan Al Mukhtariyah Al Islamiah.

Dalam agama islam berdoa merupakan suatu rangkaian ibadah yang mempunyai keterkaitan dengan keimanan dan keislaman ummat muslim. Oleh karena itu, berdoa sangat dianjurkan oleh agama, walaupun doa tidak memerlukan suatu syarat dan rukun yang ketat, seperti halnya ibadah shalat, zakat dan puasa.

Ada banyak doa pilihan yang bisa digunakan untuk berdoa, salah satunya wirdul jalil. Wirdul Jalil merupakan doa dan zikir yang disusun oleh TGH. Afifudin Adnan salah satu murid dari Mawlanasysyaikh Tuan Guru Kyai Hajji Muhammad Zainuddin Abdul Madjid dan sekaligus pendiri Yayasan Al Mukhtariyah Al Islamiyah.

Wirdul jalil sudah menjadi bacaan wajib untuk jam'ah dan murid Yayasan Al Mukhtariyah Al Islamiyah dan hampir setiap tahunnya, pondok pesantren Al Mukhtariyah Al Islamiyah mencetak wirdul jalil. Kemudian di bagikan untuk murid dan jama'ah Al Mukhtariyah Al IsImiyah untuk mengganti wirdul yang telah rusak dimakan usia atau hilang.
Berdasarkan hal tersebut, penulis tertarik membuat peneltian berbasis mobile, dengan judul "Rancang Bangun Aplikasi Al Wirdul Jalil Berbasis Mobile" yang dimana, didalam aplikasi tersebut terdapat Kumpulan doa dan zikir yang di susun oleh TGH. Afifudin Adnan. yang nantinya bisa di pasang di perangkat mobile.

\section{Tinjauan Pustaka}

\subsection{Penelitian Terkait}

Dalam melaksanakan penelitian ini perlu disertakan referensi yang terkait dengan penelitian yang dilakukan, yaitu :

Penelitian yang di lakukan oleh Hariman Bahtiar, Muhamad Wasil dan Bambang Harianto dalam jurnal yang berjudul "Digitalisasi Karya TGKH. Muhammad Zainuddin Abdul Madjid berbasis mobile sebagai media pembelajaran interaktif untuk pelestarian peninggalan pendiri Nahdlatul Wathan" yang membahas tentang digitalisasi karya TGKH. Muhammad Zainudin Abdul Madjid berbasis mobile sebagai media pembelajaran interaktif untuk pelestarian peninggalan pendiri Nahdlatul Wathan menjadi salah satu solusi akan membantu murid-murid beliau yang notabennya tidak memiliki kitab tersebut dan terhalang dengan jarak dan waktu[1][2], [3].

Penelitian berikutnya yang dilakukan oleh Hariman Bahtiar dan L. Kerta Wijaya[4] (Universitas Hamzanwadi, Lombok : 2020) dalam jurnal yang berjudul "Mobile Based Geographic 
Information System for mapping and data collection Towards 4.0 Industry" yang dimana dalam jurnal tersebut membahas penelitian tentang Sistem Informasi Geografis berbasis mobile untuk melakukan pemetaan dan pengumpulan data di Era 4.0 industry. Adapun hasil dari penelitian tersebut yaitu sebuah aplikasi untuk memproses pemetaan dan pengumpulan data yang didukung oleh sistem informasi geografis, sehingga dapat dilakukan lebih efisien dan tidak membutuhkan waktu lama dalam melakukan Penyimpanan data.

Imran Djafar dan Herlinda[5] (STMIK AMIKOM, Yogyakarta : 2016) dengan judul "Perancangan Aplikasi Doa Dan Wirid Harian Muslim Berbasis Android" adapun hasil penelitan didalam jurnal tersebut yaitu aplikasi doa dan wirid harian muslim berbasis android yang dapat mempermudah pengguna untuk mengetahui amalan sunnah (doa dan wirid) sehari-hari lewat Output Informasi Doa dan wirid yang di tampilkan yang biasa diamalkan dalam keseharian seorang muslim, yang sesuai dengan kitabullah dan sunnah rasul.

Penelitian lain yang dilakukan oleh Aris Sudianto dan Lalu Muhammad Samsu[6] (Universitas Hamzanwadi, Lombok Timur : 2019) dalam jurnal yang berjudul "Penerapan Media Pembelajaran Interaktif Pelajaran Bahasa Indonesia Berbasis Android Untuk Kelas Vii Madrasah Tsanawiyah Nahdlatul Wathan Ketangga Sebagai Upaya
Untuk Peningkatkan Minat Belajar Siswa" dimana dalam jurnal tersebut membahas tentang penerapan media interaktif Berbasis Android sebagai upaya dalam meningkatkan minat belajar siswa. Dalam penelitian tersebut menghasilkan sebuah aplikasi media pembelajaran berbasis mobile yang di dalamnya terdapat materi, kuis, video dan chat yang dapat membantu siswa dalam mengembangkan kompetensi dan menarik minat belajar siswa.

Selain itu penelitian yang di lakukan oleh Eri Satria, Dewi Tresnawati dan Cecep Saepuloh[7] (Sekolah Tinggi Teknologi Garut, Garut : 2017) dalam jurnal yang berjudul "Rancang Bangun Aplikasi Ibadah Dzikir Dan Doa Harian Berbasis Android" hasil dari penelitian tersebut yaitu :

1. Aplikasi doa dan dzikir harian yang dapat dibedakan menjadi beberapa kategori bacaan yaitu bacaan dzikir untuk pagi hari serta petang.

2. Aplikasi dzikir dan doa harian yang dapat diterapkan pada platform android supaya dapat diakses lebih praktis bagi pengguna, selain itu pengguna smartphone android di Indonesia terus meningkat dan digunakan oleh semua kalangan masyarakat.

3. Aplikasi dzikir dan doa harian dibuat dalam satu kesatuan yang belum ada sebelumnya, sehingga umat muslim dapat membaca ataupun menghafalkan berbagai doa doa dalam satu aplikasi. Aplikasi dilengkapi 
dengan fitur suara sehingga selain bisa dibaca doa doa yang ada didalam aplikasi tersebut juga bisa didengarkan secara langsung.

\subsection{Landasan Teori}

\section{Teori Rancang Bangun}

Kata "rancang" merupakan kata sifat dari "perancangan" merupakan serangakaian prosedur untuk menerjemahkan hasil analisis dari sebuah sistem ke dalam bahasa pemrograman untuk mendeskripsikan dengan detail bagaimana komponen - komponen sistem diimplementasikan.

Sedangakan kata "bangun" merupakan kata sifat dari pembangunan adalah kegiatan menciptakan sistem baru maupun mengganti atau memperbaiki sistem yang telah ada baik secara keseluruhan maupun sebagian[8].

Dengan demikian pengertian rancang bangun merupakan kegiatan menerjemahkan hasil analisa ke dalam bentuk software kemudian menciptakan sistem tersebut ataupun memperbaiki sistem yang sudah ada.

\section{Metode Penelitian}

\subsection{Tahapan Penelitian}

Adapun tahapan dari penelitian ini meliputi tahapan diantaranya :
1. Tahap pengumpulan informasi mengenai data-data wirdul jalil yang di susun oleh TGH. Afifudin Adnan.

2. Tahap Desain dan proses

System Design dilakukan berdasarkan luaran atau output oriented, artinya proses dan inputnya dilihat setelah ditentukan luaran yang diinginkan, sehingga dapat dilihat kebutuhan minimum dari suatu sistem jaringan informasi.

3. Experimen dan Pengujian

Hasil yang telah dilakukan, di uji coba untuk melihat apakah system yang dihasilkan dapat sesuai dengan yang diinginkan peneliti.

4. Evaluasi hasil experimen dan pengujian Setelah dilakukan pengujian dan experimen terhadap hasil yang dilakukan,maka bisa dilihat perbedaan dari hasil yang dilakukan sebelumnya, apakah aplikasi mobile dengan model interaktif ini dapat mempermudah santri dan santriwati yayasan Al Mukhtariah Al Islamiah dalam membaca wirdul jalil. 


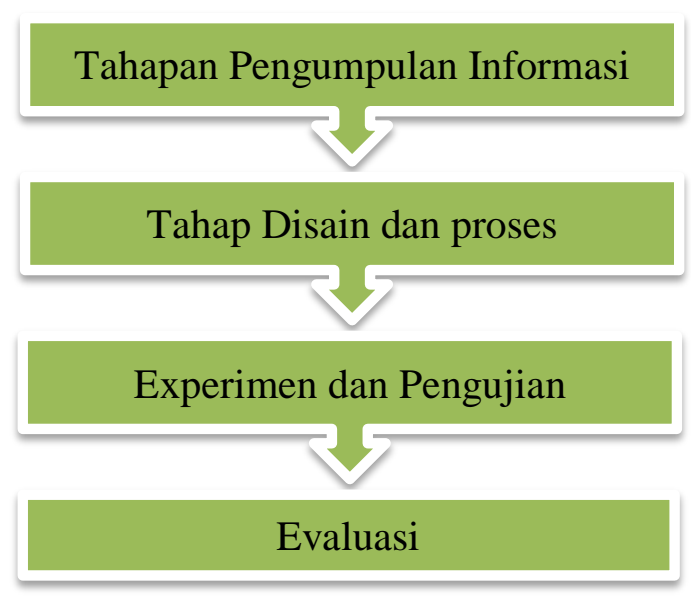

Gambar 1. Tahapan Penelitian

\subsection{Proses Perancangan dan desain aplikasi}

Proses perancangan dan desain aplikasi digambarkan dengan use case diagram seperti pada gambar 2. Sebuah use case diagram menggambarkan hubungan antara actor serta kegiatan yang dapat dilakukan terhadap aplikasi.

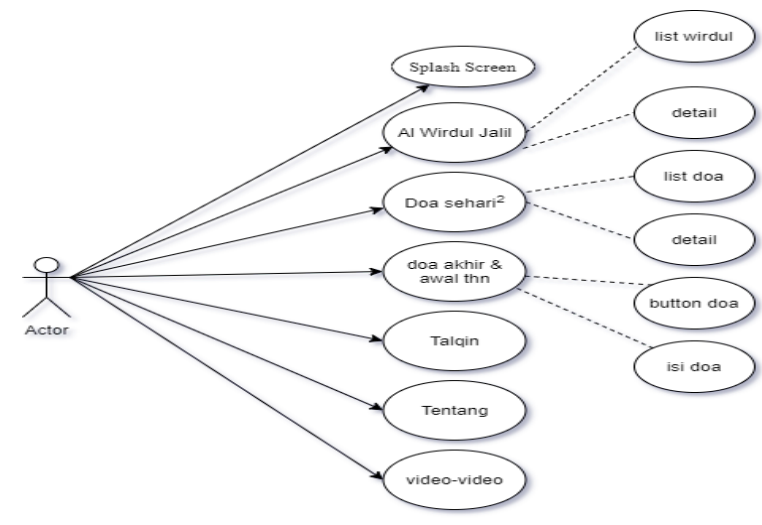

Gambar 2. Use case diagram Aplikasi AI Wirdul Jalil

\subsection{Class Diagram}

Class Diagram digunakan untuk menapilkan hubungan atara kelas-kelas atau paket-paket dalam sistem. Perancangan Class diagram dapat dilihat pada gambar 3 .

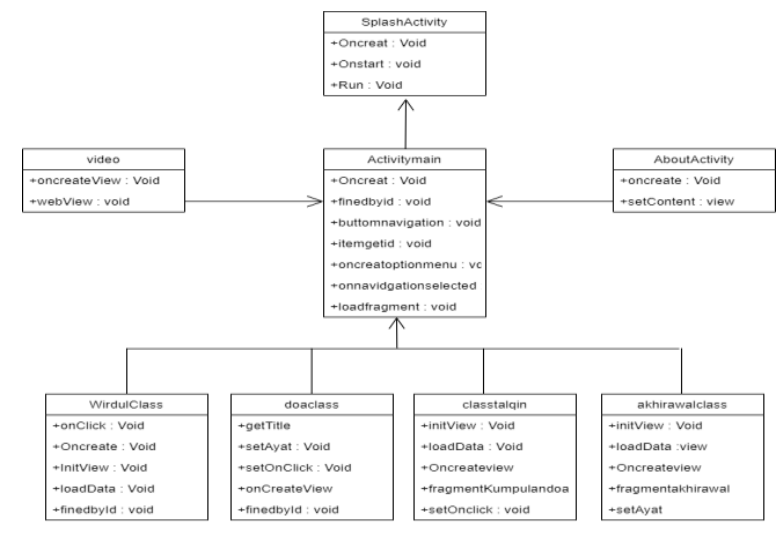

Gambar 3. Class Diagram Aplikasi AI Wirdul Jalil

\section{Hasil dan Pembahasan}

Pada tahap ini, penulis akan membahas mengenai hasil dari penelitan yang telah dilakukan terhadap implementasi sistem. Dalam penelitian yang dilakukan, sistem seharunya memiliki proses - peroses ketika pengguna mulai menjalankan aplikasi. Berikut ini adalah halaman utama yang merupakan splash screen yang akan terlihat paga gambar 4. Merupakan halaman yang akan pertama kali terlihat ketika pengguna mulai menjalankan aplikasi.

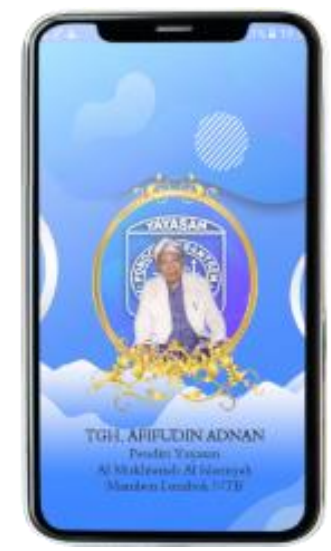

Gambar 4. Tampilan Halaman Splash Screen 
Sedangkan hasil implementasi kedua setelah splash screen, sistem akan menampilkan menu beranda yang terlihat pada gambar 4. Pada menu beranda ini, maka akan tampil 6 (enam) menu utama yang terdapat didalam aplikasi diantaranya, menu Al Wirdul Jalil, menu doa sehari-hari, menu doa talqin, menu video, menu tentang, menu doa Akhir dan Awal tahun.

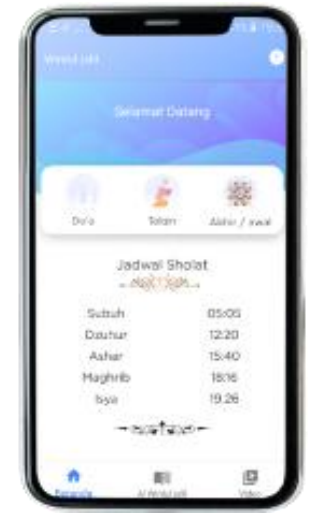

Gambar 5. Tampilan Halaman Beranda

Pada Gambar 5 merupakan contoh ketika pengguna memilih menu AI Wirdul Jalil.
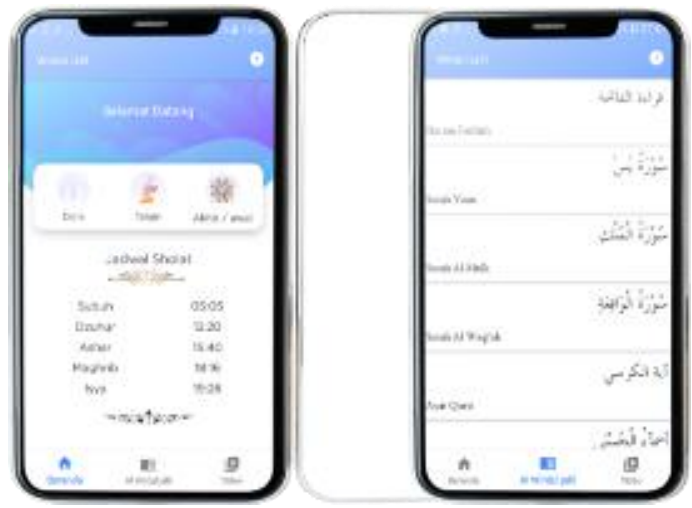

Gambar 6. Tampilan Halaman lis Al Wirdul Jalil Pada Gambar 6 Merupakan menu list yang berisikan kumpulan doa dan zikir yang terdapat didalam Al Wirdul Jalil, dengan adanya list-list doa dan zikir tersebut pengguna akan lebih mudah dalam menggunakan aplikasi.

Sedangkan pada gambar 6. Merupakan contoh apabila pengguna memilih salah satu list yang terdapat pada halaman AI Wirdul Jalil.
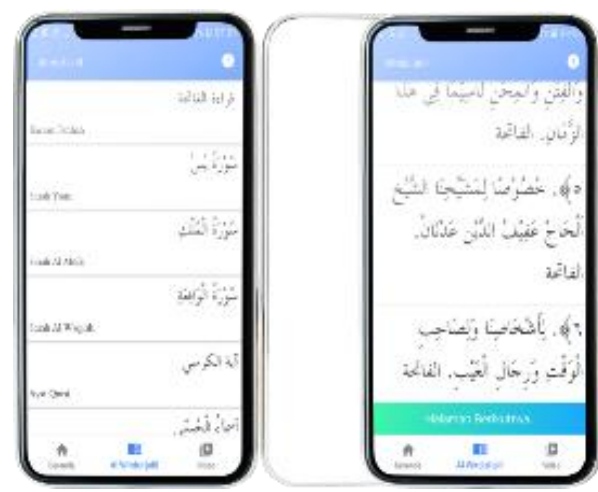

Gambar 7. Tampilan Halaman Detail AI Wirdul Jalil

Pada Gambar 7 Menunjukkan bahwa, ketika pengguna mengklik salah satu list doa yang tedapat pada halaman Al Wirdul Jalil, maka pengguna akan di alihkan ke menu detail doa yang telah di pilih. Kemudia pada akhir doa tedapat button "halaman berikutnya" yang apabila di kelik akan mengarah ke doa dan zikir berikutnya.

Kemudian pada gambar 8. Merupakan contoh ketika pengguna mengklik menu Do'a.

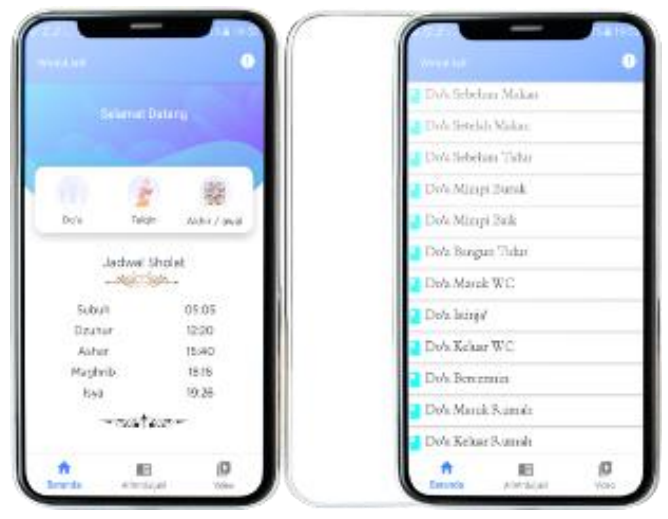


Gambar 8. Tampilan Halaman Doa Sehari-hari

Pada gambar 8, tersebut menampilkan list doa yang di baca sehari-hari seperti doa makan, doa minum dan lain-lain. Tampilannya tidak jauh berbeda seperti yang terdapat pada menu Al Wirdul Jalil.

Pada gambar 9. Merupakan contoh ketika penggunaka mengkelik menu Do'a.

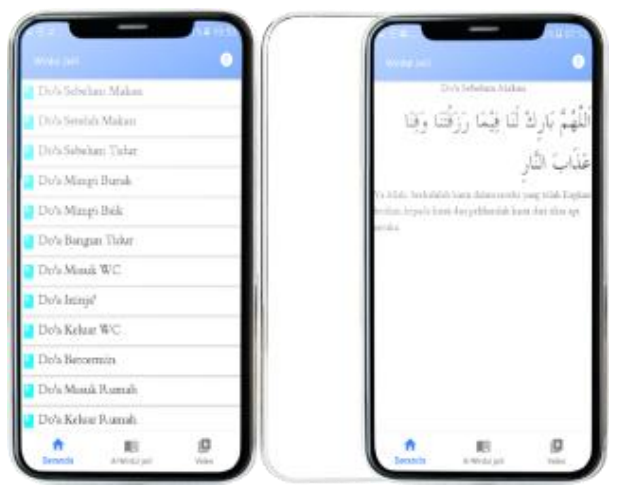

Gambar 9. Tampilan Halaman isi Doa sehari-hari Dalam gambar 9 , terdapat isi dari doa sehari-hari lengkap dengan terjemahan dalam bahas indonesia.

Kemudian pada gambar 10, merupakan contoh apabila pengguna mengklik menu talqin.
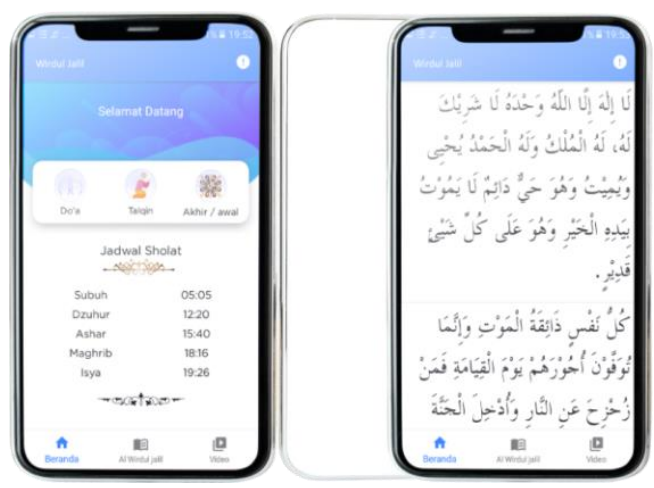

Gambar 10. Tampilan Halaman doa Talqin
Dalam gambar 10. Terdapat doa talqin, doa yang senantiasa di baca pada saat memakamkan mayit.

Pada gambar 11. Merupakan contoh ketika pengguna mengklik menu Akhir / Awal,

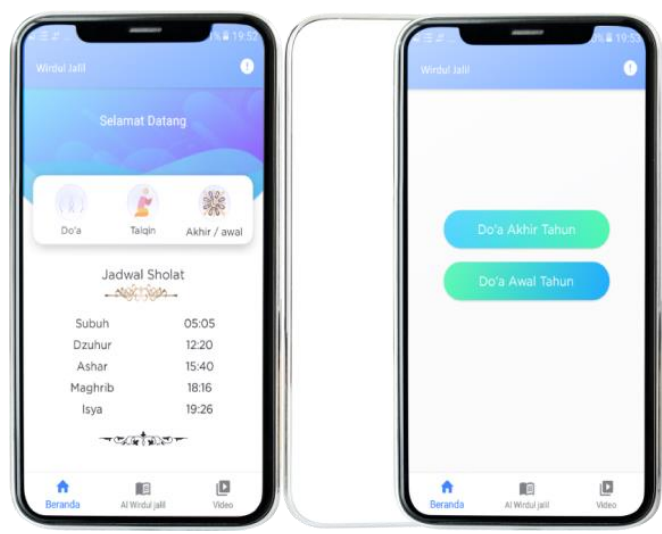

Gambar 11. Tampilan Halaman Akhir/Awal

Dalam gambar 11. Terdapat 2 button diantaranya button doa Akhir tahun dan button doa Awal tahun, yang apabila di kelik salah satu maka akan diarahkan ke doa yang sesuai button yang di kelik.

Kemudian pada gambar 4.31. Memperlihatkan isi doa dari salah satu button yang terdapat pada halaman "Akhir / Awal"
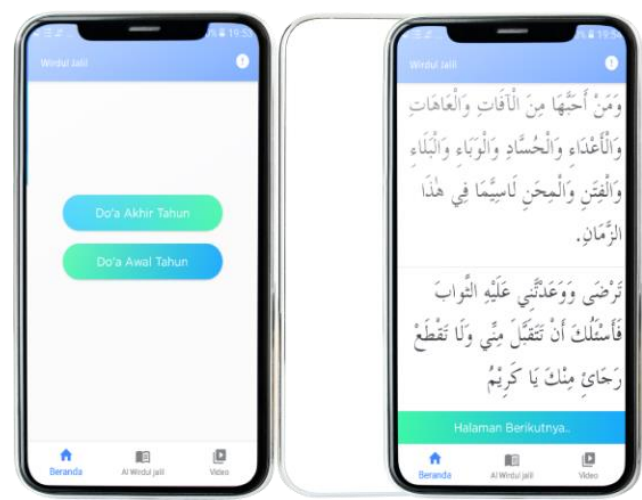

Gambar 12. Tampilan isi button doa Akhri / Awal tahun 
Pada gambar 12, ini terdapat isi dari doa salah satu button yang di kelik pada halaman menu "Akhir / Awal", seperti pada pada menu Al Wirdul Jalil. Di bagian akhir doa terdapat button "halaman berikutnya" yang dapat di kelik untuk melanjutkan ke doa Awal tahun atau sebaliknya.

Pada gambar 13. Merupakan contoh ketika pengguna mengklik menu video.

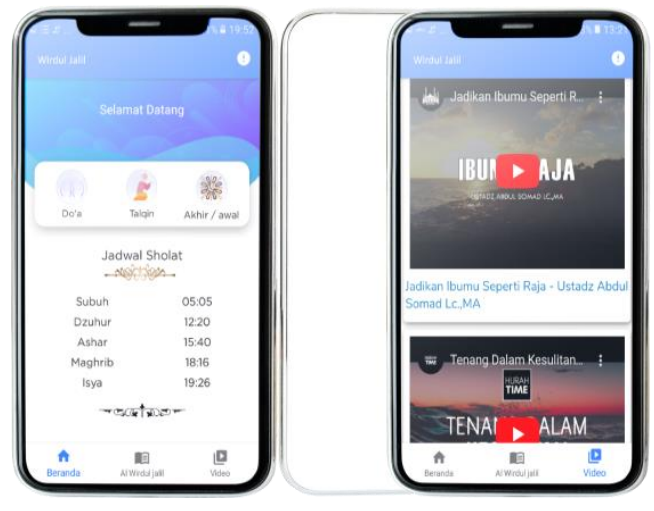

Gambar 13. Tampilan Halaman menu Video

Dalam gambar 13. Ini akan menampilkan halaman yang berisi video-video dakwah dan nasehat islami yang di peroleh dari berbagai media, seperti youtube dan media-media lainnya. Kemudian pada gambar 14. Merupakan contoh ketika pengguna mengkelik menu tentang yang terdapat pada pojok kiri atas yang dilambankan tanda "!" warna putih.

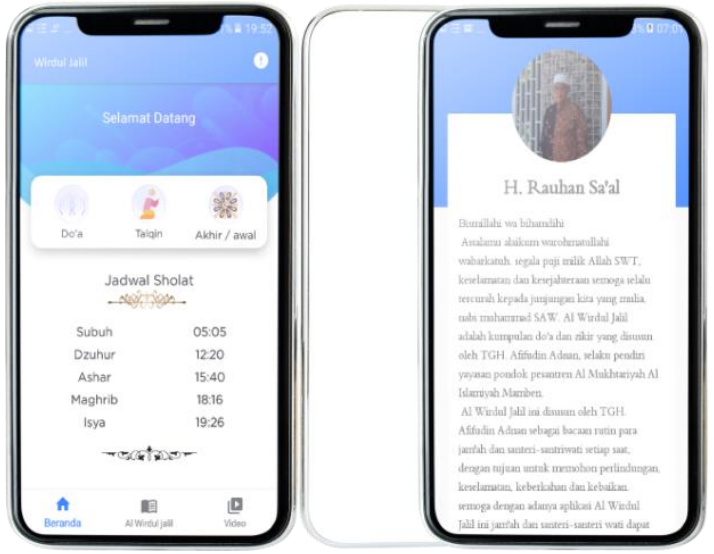

Gambar 14. Tampilan Halaman menu Tentang

Pada gambar 14, ini pengguna akan melihat infromasi tentang aplikasi dan profil singkat tentang depelover aplikasi.

\section{Kesimpulan}

Berdasarkan dari hasil penelitan dan pembahasan, mengenai hasil penelitian yang berjudul "Rancang Bangun Aplikasi Al Wirdu Jalil Berbasis Mobile" Maka dapat di tarik kesimpulan sebagai berikut "Aplikasi Al Wirdul Jalil tidak hanya berisi tentang Doa Al Wirdul Jalil namun ada 5 (enam) fitur yang menjadi tambahan di dalam aplikasi, sehingga dalam satu aplikasi ada 6 (enam) pilihan fitur yang dapat di manfaatkan oleh pengguna. Adapun ke 6 (enam) fitur tersebut diantaranya iyalah :

1. Fitur Al Wirdul Jalil

Fitur ini berisi tentang kumpulan doa dan zikir yang tersusun di dalam buku cetakan Al Wirdul Jalil yang disusun oleh TGH. Afifudin Adnan yang kemudian di dalam aplikasi di tampilkan dalam bentuk lis, dan apabila 
salah satu lis di kelik maka akan mengarah ke doa yang terdapat dalam Al Wirdul Jalil, pada bagian bawah doa terdapat button "Halaman berikutnya" yang ketika di kelik akan mengarah ke doa berikutnya yang terdapat pada AI Wirdul Jalil.

2. Fitur Kumpulan Doa Sehari-hari

Di dalam fitur Doa sehari-hari ini, terdapat kumpulan doa-doa yang dibaca setiap hari. Seperti doa makan, doa sebelum tidur, doa masuk WC dan masih banyak lagi doa-doa yang lainnya.

3. Fitur Doa Talqin

Doa talqin merupakan doa yang sering di baca ketika memakamkan jenazah, doa talqin ini juga terdapat di dalam buku cetakan Al Wirdul Jalil. Dengan adanya fitur ini diharapkan dapat membantu orang yang belum menghafal doa tersebut.

4. Fitur doa Akhir dan Awal tahun

Fitur ini berisi doa Akhir tahun dan Awal tahun yang sering di baca oleh seluruh ummat muslim ketika tanggal 1 muharram, doa ini juga sering di baca oleh para jam'ah dan santri/wati yayasan pondok pesantren di setiap tahun baru islam.

5. Fitur Video

Fitur video ini menampilkan video-video ceramah dan nasehat-nasehat agama yang diproleh dari berbagai sumber, seperti youtube dan media-media lainnya.
6. Fitur tentang.

Di dalam fitur ini, berisi infromasi keterangan aplikasi, dan profil pengembang aplikasi.

- Aplikasi ini memiliki perpaduan warna biru dan putih, sesuai dengan ciri khas Yayasan Pondok Pesantren Al Mukhtariah Al Islamiyah. Tujuannya agar jam'ah dan santeri/wati pamiliar dengan aplikasi.

\section{Daftar Pustaka}

1] Hariman Bahtiar; Muhamad Wasil; Bambang Harianto, "Digitalisasi Karya TGKH. Muhammad Zainuddin Abdul Madjid berbasis mobile sebagai media pembelajaran interaktif untuk pelestarian peninggalan pendiri Nahdlatul Wathan," Infotek J. Inform. dan Teknol., vol. 88, no. 5, pp. 427-434, 2019.

[2] H. Bahtiar, A. E. Sutriadi, M. Djamaluddin, and T. Barat, "Digitalisasi Kitab Nadham Batu Ngompal Karya TGKH . Muhammad Zainuddin Abdul Madjid Berbasis OPF Flipbook Pulau Lombok sebagai salah satu pulau yang mempunyai potensi yang cukup besar untuk dijadikan objek wisata - Dengan keindahan alam dan keanekaragaman," Infotek J. Inform. dan Teknol., vol. 3, no. 2, pp. 1-8, 2020.

[3] H. Bahtiar, M. Djamaluddin, L. M. Samsu, and K. L. Timur, "Digitization of Hizib Nahdlatul Wathan by TGKH . Muhammad Zainuddin Abdul Madjid Based on the OPF Flipbook," IAIC Int. Conf., vol. 3, no. 1, pp. 20-25, 2020.

[4] H. Bahtiar and L. Kerta Wijaya, "Mobile Based Geographic Information System for mapping and data collection Towards 4.0 Industry," J. Phys. Conf. Ser., vol. 1539, no. 1, pp. 0-5, 2020.

[5] H. Djafar, "PERANCANGAN APLIKASI DOA DAN WIRID HARIAN MUSLIM 
BERBASIS ANDROID," Teknol. Inf. dan Multimed., pp. 6-7, 2016.

[6] Aris Sudianto and L. M. Samsu, "Penerapan Media Pembelajaran Interaktif Pelajaran Bahasa Indonesia Berbasis Android Untuk Kelas Vii Madrasah Tsanawiyah Nahdlatul Wathan Ketangga Sebagai Upaya Untuk Peningkatkan Minat Belajar Siswa," vol. 2, no. 2, pp. 5-10, 2019.

[7] E. Satria, D. Tresnawati, and C. Saepuloh, "Rancang Bangun Aplikasi Ibadah Dzikir Dan Doa Harian Berbasis Android," J. Algoritm., vol. 14, no. 2, pp. 368-372, 2015.

[8] M. Triputra, E. S. Susanto, and W. Ismiyarti, "Rancang Bangung Aplikasi Klasifikasi Plagiarisme Dengan Memanfaatkan Machine Learning Berbasis Android," J. JINTEKS, vol. 1 (1), no. 1, pp. 87-96, 2019.

[9] Z. R. S. Prakosa, "APLIKASI DOA SEHARI-HARI BAGI UMAT MUSLIM BERBASIS ANDROID," no. June, 2016.

[10] Sadeli, "APLIKASI AL-QURAN BERBASIS ANDROID MENGGUNAKAN METODE SEQUENTIAL SEARCH," J. Chem. Inf. Model., vol. 53, no. 9, p. 287, 2008.

[11] Ahmad Zainudin, "Pengenalan android," Forum Android Indones., 2016.
[12] M. Ulum, M. Idris, P. S. Informasi, P. Manajeman, and P. Islam, "ANALISA APLIKASI PENGHAFAL DOA - DOA ISLAM BERBASIS ANDROID UNTUK MENINGKATKAN MINAT," vol. 5, no. 1, pp. 11-22, 2019.

[13] I. P. Gede, A. Sudiatika, K. Hari, and A. W. Putra, "Implementasi Android Studio Sebagai Media Terapi Pengenalan Toilet Untuk Anak Autis," pp. 102-105, 2017

[14] A. Sudianto and H. Ahmadi, "Rancang Bangun Sistem Informasi Penjualan Sparepart Motor Pada Bengkel Vinensi Motor Berbasis Web," Infotek J. Inform. dan Teknol., vol. 3, no. 2, pp. 32-39, 2020

[15] S. M. Sudianto Aris, "Penerapan Sistem Informasi Geografis (GIS) dalam Pemetaan Kerajinan Kain Tenun dan Gerabah untuk Meningkatkan Potensi Kerajinan di Kabupaten Lombok Timur," Infotek J. Inform. dan Teknol. J. Inform. dan Teknol., vol. 1, no. 2, pp. 64-71, 2018.

[16] L. K. W. Sudianto Aris, Nurhidayati, "Penerapan Sistem Informasi Geografis Untuk Pemetaan Bengkel Tambal Ban di Kecamatan Selong Kabupaten Lombok Timur," Infotek J. Inform. dan Teknol., vol. 3, no. 1, pp. 51-57, 2020, doi: 10.1029/2019GH000237 